\title{
How do the Results Given by International Rating Agencies Penalize Spain? Criteria to Analyse the Country Risk and to Determine the Risk Premium
}

\author{
J. Vicente Fruet-Cardozo a , Juan antonio Cañas-Madueño a , José \\ RAMÓN MILLÁN DE LA LASTRA ${ }^{\text {a }}$ \\ a Universidad de Córdoba, Fctad. de Derecho y CC.EE, Plaza de Puerta Nueva s/no, 14002 \\ Córdoba,España.E-mail: jvfruet@uco.es, es1camaj@uco.es, es1milaj@uco.es
}

\begin{abstract}
Within the last few years, the main international rating agencies have become even more prominent. They are mentioned in different circumstances. Some people think these agencies are managed by international speculators; others consider that their work is too technical and impartial, and others believe they should be replaced by exclusively European rating agencies. As seen, there are several opinions, but the fact is that financial analysts' recommendations and investors' decisions, concerning a real, financial economy, are based on the rating given to sovereign debts and companies quoted in international financial markets.

This article uses a methodology concentrating the different criteria used by two of the main international rating agencies: Standard and Poor's and Moody's. Spain is the country analyzed and this is done from four points of view: political, economical, solvency, and liquidity. The data compared ranges from December 2001 to December 2012. The results show an evident and general deterioration.

Keywords: Country Risk, Country Analysis, International Rating Agencies, Risk Premium, Global Risk Index, Politic, Economic, Solvency, and Liquidity Indicators, Spain.

\section{¿Cómo las agencias internacionales de rating califican a España? Criterios para el análisis del Riesgo-País y para determinar la Prima de Riesgo}

\section{RESUMEN}

Durante los últimos años, las agencias internacionales de calificación han ganado una notoriedad innegable. Ellas son mencionadas en todos los niveles. Algunas personas piensan que las agencias son manejadas por los especuladores internacionales, otras consideran que su trabajo es altamente técnico e imparcial, y otras opinan que deberían ser reemplazadas por agencias de calificación exclusivamente europeas. Sin embargo, la realidad es que las recomendaciones de los analistas financieros y las decisiones de los inversores en la economía real y financiera se basan en los ratios que estas agencias otorgan a la deuda soberana y los títulos de las empresas cotizados en las bolsas de valores.

El artículo utiliza una metodología que concentra los diferentes criterios empleados por dos de las principales agencias de calificación: Standard \& Poor's and Moody's. España es el país analizado y se efectúa desde cuatro puntos de vista: político, económico, de solvencia y de liquidez. La comparación de los indicadores corresponde a Diciembre del 2001 y Diciembre de 2012, y los resultados muestran un deterioro generalizado evidente.

Palabras clave: Riesgo-país, Análisis de país, Agencias internacionales de calificación, Prima de riesgo, Indicador global del riesgo, Ratios políticos, económicos, de solvencia y de liquidez, España.

JEL Classification: G1, G15

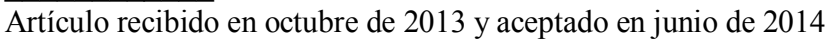

Artículo disponible en versión electrónica en la página www.revista-eea.net, ref. ə-32312 


\section{INTRODUCTION}

\section{a. General Information}

Within the last few years, international rating agencies have become even more prominent. They are heard about in various conversations and different circumstances. Some people think these agencies are managed by international speculators for their own benefits; other people consider their work is too technical and impartial, and others believe they should be replaced by exclusively European rating agencies ${ }^{1}$.

Different opinions exist, although the fact is that financial analysts' recommendations and investors' decisions concerning a real and financial economic, are based on the rating that the agencies give to sovereign debts and companies quoted in international financial markets.

Within the last decades, capital flight has been common when investors have decided to change the country and settle it in another, where they would find the expected benefits. This decision would have been made because the initial country would not offer the desired profitability. Nevertheless, the current problem of those nations receiving the investment is that this capital flight happens as soon as the broker presses the "Enter" key on a computer's keyboard. In a second, thousands of millions of dollars, euros, yens, pounds, or any other significant currency is transferred from Madrid to Hong Kong, London to Sao Paulo, or from Dubai to New York. As a result, the financing levels of countries decrease along with all the negative consequences this might involve. Therefore, in order to bring the money back, a plus, derived from the analysis and subsequent rating from those international rating agencies, has to be paid.

However, Eaton and Stiglitz (1986) consider that investors should not base their final decisions solely upon those ratings, since they only evaluate one risk aspect: the default ${ }^{2}$.

\section{b. The Role of the Rating Agencies}

Regarding these agencies, we have to point out that there are more than seventy in the world. However, the three most prestigious agencies are: in first place, Standard \& Poor's, second, Moody's, and third, Fitch. The three of them, stationed in New York, form an oligopoly which owns $90 \%$ of the world market.

\footnotetext{
${ }^{1}$ On September 2010, the European Union issued a list of regulations for rating agencies whose aim was to regulate the integrity and transparency in the rating process. Furthermore, on April 2012, they added four new proposals to this regulation. Some employees in these agencies suggest that those proposals "might damage investors, companies, and European economy".

${ }^{2}$ Eaton, J.; Gersovitz M.; Stiglitz, J.E. The Pure Theory of Country Risk. Elsevier Science Publisher B.V. 1986.
} 
As we have seen in the last few years, governments and multinationals should thoroughly understand the ratios and variables in this field, because whenever a rating agency downgrades sovereign debts, it has a significant impact on the so-called "risk premium". Hence, the downgrading has two parts: first, the one related to methodology, criteria, and procedures which rating agencies use to assess and rate a country, and second, the impact which downgrading has on the risk premium. The present article is an adaptation and reclassification of the methodologies and criteria used by Standard and Poor's and Moody's, in order to be a more academically comprehensive model.

\section{c. Considerations About "Risk Premium"}

Before delving into this topic, the significance of "risk premium" is explained. On the one hand, in general terms, the "risk premium" is an extra payment (increased interest or dividend, or higher, than usual profits) associated with more risky investments. And, on the other, in relation to our paper specifically, it refers to the differential in interest rate, paid for sovereign debts issued by a country. The debt used as a standard is a ten-year government bond. The differential in rate is compared to similar bonds issued by another country whose economic behaviour is acceptable as reference in the region. In the Euro zone, for example, Germany is the reference country.

From academic and technical standpoints, the differential between interest rate within two countries reflects in two different ways: on one hand, the inflation rate between them, and on the other, the default risk perceived by the market. However, from a real market's point of view, it must be recognized that in this equation there are other variables always present: rational and irrational expectations about a market's volatility. In order to understand the impact of risk premium on the national economy, we are going to mention the Spanish case recorded on December $31^{\text {st }}, 2012$. The interest rate for ten years of Treasury bonds was $5.26 \%$, while the German bond was only $1.32 \%$. In that case, the risk premium assumed by Spain was 3.94\%, which in financial market terminology would be presented as 394 basis points (394bps).

\section{d. Summary - "Country Risk Analysis"}

What is remarkable is that the main three rating agencies analyse ratios that show political, economic, solvency, and liquidity aspects of a country. ${ }^{3}$ Each one of those includes weights and rates which lead to a mathematical model,

\footnotetext{
${ }^{3}$ Each one has its own methodology, procedures, and criteria in general but all of them coincide in these factors. For example, Standard \& Poor's, currently applies five criteria: (a) institutional effectiveness and political risks, (b) economic structure and growth expectations; (c) external liquidity and external investment position; (d) fiscal development, flexibility, and debt level; and, (e) monetary flexibility.
} 
which then later creates a more technical and objective result. We know that a mathematical model is a way to represent political and economic happenings of a country. Success or failure of a mathematical model shows the precision by which it represents the reality and not the accuracy by which mathematics analyse the model. This is the result that has been used for more than two decades and therefore, should be considered, at least technically valid. Consequently, the opinion that states that everything that surrounds the "Country Risk" is only speculative, and should not be included in an academic or professional context ${ }^{4}$.

To summarize, this research work presents an adapted methodology, based on concepts and procedures that concentrate the different criteria used by Moody's and Standard \& Poor's, in order to analyze the Country Risk, and so, to rate the government debt ${ }^{5}$. Each one of these agencies has its own method and criteria rate, but we have tried to fuse them into one model.

We know that these rating agencies made important mistakes, as can be seen in any company, and they might keep making mistakes. However, it would be unwise to dismiss their ratings because, as was mentioned before, the assessment results of these agencies form an objective, authorized, and relevant opinion, which can later be used by large companies in worldwide financial markets.

\section{BASIC CONCEPTS}

\subsection{Country Risk}

In accordance with García Gámez, S. Vicéns Otero, J. (2006), and Pampillón Olmedo, R. (1999), Country Risk refers to the exposure of a loss which an investor is endangered to due to economic and sovereign issues in a country. At the same time, it is divided into Political Risk and Transfer Risk. Political Risk is the risk that investors and moneylenders suffer as a result of political factors regarding repatriation of capitals, interest, dividends, etc. For instance, the nationalization of YPF-Repsol by the Argentinean government is a clear example of political risk. As mentioned, the second sub-part of a Country Risk is the Transfer Risk. This is the risk derived from the impossibility to repatriate capital, interest, and dividends due to the economic situation of a country and, specifically, due to the lack of currency in the moment of the capital's repatriation ${ }^{6}$.

\footnotetext{
${ }^{4}$ The "Risk Premium" increases notoriously just previous days before the issue of the Spanish bond treasuries.

${ }^{5}$ Appendix 1 and 2, show Moody's and Standard \& Poor's methodologies, respectively.

${ }^{6}$ There are other risks for those countries which do not belong to the "First World" which are related to "Currency risk" and "Legal risk". The last one is due to intervention of different countries' legislations.
} 
Methods and ratio structures used by international rating agencies to calculate the Country Risk are based upon the same concepts and these constitute estimates on quantitative and qualitative variables. Picking out and weighing these variables is carried out by a multidisciplinary experts' team whose top priority is objectivity.

\subsection{Sovereign Risk}

According to Gültekin-Karakas, D., Hisarciklilar, M., and Öztürk, H. (2011), Sovereign Risk is the risk assumed in an investment where the debtor is a Sovereign State. It should not be confused with Country Risk where the debtor is the government of a country or a private company.

Nonetheless, it is also important to declare that even if the influence of macroeconomic and financial aspects outside the current globalized world is considered, the increase in Country Risk is usually due to an inappropriate economic management of a country's government.

\subsection{Country Analysis}

In order to analyse the Country Risk, a "Country Analysis" has to be previously done. In this analysis, different kinds of risks, to which the nation is bound, are identified, which are the political, economic, solvency and liquidity risks. The final result of this analysis is the Global Risk Index, used to obtain the "Country's rating" expressed by the following letters: AAA, AA, A, BBB, $\mathrm{BB}, \mathrm{B}$, etc. .

\section{HOW CAN WE MAKE A "COUNTRY ANALYSIS"?}

In general, the leading international rating agencies use a similar methodology to analyze countries based on various main aspects: political, economic, solvency, and liquidity, among others. Following this, four of the most important ratios, that we consider, are presented.

\subsection{Analysis of the Main Political Indicators}

Of all four analyses, the most relevant is the political analysis. This is due to the fact that this analysis is the one with the heaviest ranking weight. It is very important to state that a government team without the adequate management skills, impacts the economic results of a country ${ }^{8}$ both negative and immediately. Analysis factors related to the "political indicator" are risks derived

\footnotetext{
${ }^{7}$ In 3.2., Chart 2, there is a classification by agencies, letters, and marks.

${ }^{8}$ Argentina is a clear example: in the 1950 's, it was the world's $7^{\text {th }}$ largest economy and nowadays its worsening is evident. Furthermore, the opposite can be seen in countries such as Japan and South Korea, whose economies have made a $180^{\circ}$ flip turn within the last 50 years.
} 
from political weakness, instability, corruption, the effect of certain pressure groups, and the potential effect of international organizations on the definition of their national policies. As a result, the first thing investors observe -in countries analyzed by rating agencies- is the political scenario. Sometimes, from an economic and geographic standpoint, a country can be potentially viable for investments, but the current political regime of that country may not help ${ }^{9}$. If political ratios of a country do not show a good result, it will negatively affect the other three ratio structures: economic, solvency, and liquidity. This can be proved by the mathematical formula applied in the methodology ${ }^{10}$. Also, because political ratios are heavier, the final result will not be favourable for the country. The main indicators of this analysis are mentioned immediately afterwards.

- Political regime: a mature democratic system is the best first impression of a country.

- Pressure groups: when there are strikes, uprisings and disturbances. An investment does not desire any kind of "turbulences".

- Corruption level: it is probably a country's worst first impression for investors.

- Separatist movements: these groups plot against political stability of a country, and it is very negative for the so-called "country marking". Currently, in Spain, this factor represents one of the most negative political sub-ratios ${ }^{11}$.

- Membership of international organizations: being a member of an international organization has a big influence on a country's economy and it is quite strategic.. The importance the EU had and has for Spain, or any other member country, is simply vital.

- Economic system: there are different economic systems that range from a planned economy to a free-market economy. Efficiency and attitude towards foreign investments vary between economic systems. This sub-ratio is included among the political analysis because, from a rating agency's point of view, this is related to the economic model implanted and applied by the government during the analyzed period.

\footnotetext{
${ }^{9}$ A current and very clear example is Iran.

${ }^{10}$ As it is mathematically known, when multiplying factors, the final result concentrates the nature of each factor.

${ }^{11}$ Independent movements lead regional product exports, with their own local trademark, which is unknown abroad. These products have to compete with other similar products from wellknown countries which are sometimes powerful. These kinds of situations discourage investors who prefer a more homogeneous country.
} 
- Area and orography: the geography's aspects, surface area, natural resources, climate, and possibility of severe natural disasters are also analyzed.

- Other political indicators: foreign affairs, bureaucracy level, racial, religious and social structure, international conflict probability, and third country interventions, among others.

Summarizing, the political analysis assesses how governmental institutions and their policies affect a country's credit. An efficient and sustainable public management tends to lead an economic growth and an appropriate investment climate.

\subsection{Analysis of the Main Economic Indicators}

The second important analysis refers to economic ratios. The study begins analyzing the country's relations with the major multilateral institutions, particularly, their opinions and recommendations to improve the economic global scene of a country. Afterwards, the evaluation focuses on the main macroeconomic indicators.

\subsubsection{International Economic and Financial Institutions}

Before listing the main economic indicators, it is important to mention the most relevant institutions regarded as the sources to obtain macroeconomic and debt information:

- The International Monetary Fund (IMF) and the World Bank (WB): experts of IMF and the World Bank, in spite of their failure in some thirdworld country missions, are considered to be very competent in economics and finance. Therefore, the data they provide on their reports and papers is highly reliable.

- The European Union (EU): this is the most important organization for the 28 member countries, and it has the most reliable source of information.

- The United Nations Development Program (UNDP): the annual report of UNDP is a key information source. For instance, UNDP's Human Development Index of countries is its most important document. It is used to assess social aspects of nations.

- Other international and national organizations of reference are: the InterAmerican Development Bank (IDB), the African Development Bank, the Asian Development Bank, Central Banks, the Ministry of Economy and Finances, and National Statistical Institutes. 


\subsubsection{Main Economic Indicators}

- Economic policies: these indicate public and private economies' status, their aims to determine if they are efficient and competitive enough in specific sectors, and if they are able to build trust in foreign investments. Besides, they are related to the predicted changes in economic policies included in the "National Plan". Furthermore, if they qualify, they are included in the nation's general budget; besides, if official data and publications are reliable, and their workers are responsible for the economic and financial direction. In addition, analysts assess the private sector's opinion regarding economic management.

- Economic management: not only do we study if the correct policies are being applied, but also if the means they count with (quality and data reliability, official forecasts for the economy, and suitability and quality of authorities and officials) are acceptable and can be used.

- Fiscal policies: they assess the State's budget, taxes, and public spending in order to ensure and keep the economy stable.

$G D P$ and GDP per capita: these amounts are given in real and current monetary terms. Their changes are analyzed, and also the components which participate in these changes.

Employment and labourpolicies: the way labour relations are established could create conflicts affecting not only the economy but also a government's stability. For instance, the rigidity of employment favours an insufficient assessment in this ratio.

- Inflation: this has its origin in the economic policy, and its cause lies on an excessively expansionary budget and monetary policy. For instance, the analysts may ask themselves, "What is this?", "Can it be controlled or not?" This should also be compared with the inflation of the countries with which the country maintains most of its international trade, as this influences the exchange rate, and hence, the competitive position of the country to export.

- Debt level: the debt quantity regarding the possibility of a country to pay it back; it is related to its GDP, balance of payments, and its reserves. The most used indicator is ${ }^{12}$ :

${ }^{12}$ The debt with regards to GDP has been questioned lately by financial experts like Sala-i-Martín. He thinks the debt should be measured regarding the capacity a country has to give back money, because the GDP does not represent the capacity to repay the debt. The state cannot appropriate all the GDP; in fact, it should consider only the taxes and deduct costs which are committed (unemployment compensations, public workers costs, etc.). 


$$
\frac{\text { Sovereign debt }}{G D P} * 100
$$

In the early 90's, the World Bank recommended to keep this ratio under $30 \%{ }^{13}$. If this percentage increased, measures were taken in order to decrease it. However, this recommendation did not succeed and was ignored even by multilateral lending organizations -and, of course, by international investors- resulting in worrisome percentage level rises. Furthermore, on December $31^{\text {st }}$, 2011, the net public debt in Spain rose up to EUR 734,961 million: EUR 559,459 million from the Central Government and EUR 175,502 million from regional governments and town halls. Therefore, the debt represented a $68.5 \%$ GDP, a percentage which exceeded by $8.5 \%{ }^{14}$ the Stability and Growth Pact of the European Union. According to the Finance and Economy minister, by the end of 2012 , it would have risen up to $79.8 \%$ GDP. In the European Union, the average is $90.4 \%$.

- Financial system: the lending and deposit interest rates are analyzed, and also, if the credit access is fluid. Summarizing, if the transfer of savings is efficient towards the productive sector. Finally, which percentage is represented by the financial system in relation to the real economy.

- Resources and infrastructures: this part of the analysis studies the structure of roads, ports, airports, energy sources, technological development, etc. Lately, human resources of a country are a very important economic sub-ratio.

- Current account balance, commercial, service, and transfer balances: sometimes, the balance of payments examination is made separately from the economic analysis. With regard to this matter, there are two factors being studied: the components of the current account balance, and the world market situation related to the main product this country exports. In the income balance ${ }^{15}$, its evolution and composition of the capital account -in short and long term- are examined. It is estimated that capital movements originate due to an appropriate political climate for capital accumulation in a country.

- The evolution, composition, distribution by geographical area of products and immigrant's remittances are also studied. Likewise, other component

${ }^{13}$ The World Bank. Country Economics Department. 1990. A Revised Minimum Standard Model for Chile. Washington D.C., United States.

${ }^{14}$ This $8.5 \%$ cannot be mixed with the fiscal deficit of December $31^{\text {st }}, 2011$.

${ }^{15}$ Incomes and payments for labour and capital profits obtained outside the country by residents leaving abroad or paid by residents in the rest of the world. These are labour and investment profits (direct and financial investments). 
which is not part of the current account balance is also analyzed; for instance, the variations in the foreign exchange reserves. It is an important indicator of the capacity of a country to cope with its debts.

- Related to the world market situation and the main products of the country, first, the price fluctuation of the main exports is analyzed. Then, in second place, the quantities are studied.

- Nationalization: nationalization policies have a negative impact in the assessment of this indicator. Nevertheless, it is important to know if it is part of the program and know the philosophy of the current or future government regarding this issue, as it is the case in Argentina.

\subsection{Main Solvency Indicators}

The solvency analysis of a country refers to the ability to pay back the bonds of 10 years in forward. The main sub-ratios are:

- Debt level

- Debt service ratio: is related to the debt level, and the commercial relation of the country with the rest of the world is the so-called Debt Service Ratio (DSR). The formula is:

$$
D S R=\frac{\text { Debt service }}{\text { Current account balance }} * 100
$$

A DSR of around $20 \%$ or less is acceptable. A DRS over $25 \%$ could bring a solvency problem.

- Debt structure: apart from payable amounts, due dates, and repayment currencies ${ }^{16}$, interest rate and main creditors also have to be analyzed.

- Public debt / GDP

- Currency depreciation and devaluation: the Euro is the second strongest currency in the world. In this sense, the possibility of currency devaluation is a key factor. This would be the case if the country needed to export more products, and that way, acquire more currencies to be able to afford the debt. Devaluation is related to governmental economic policies, and impacts directly on the balance of payments. Not a single Euro zone country can devaluate the euro unilaterally. This situation has its advantages and disadvantages. The main advantage is the security on the ex-

\footnotetext{
${ }^{16}$ For developing countries, loans granted by the World Bank or the Inter-American Development Bank are normally expressed in US dollars, but the cancellations are made depending on currency needs that these institutions need at loan maturity. As a result, the disbursement could be made in dollars or yens, but the repayment must be made in Euros or Swiss francs, for instance.
} 
change rate, and the weakness is the countries' impossibility to devaluate that currency.

\section{4. Main Liquidity Indicators}

The liquidity analysis of a country represents the ability to pay back the short-term debt, five years from the present moment ${ }^{17}$. The main sub-ratios are:

- International monetary reserves (IMR) / Monthly imports: although these are not the only liquidity source, the international reserves show the capacity of a country to afford the short-term proportion of its debt. The reserves could constitute currency or gold ${ }^{18}$. The most popular ratio about this international-reserve level on monthly imports is:

$$
\frac{I M R}{\text { Monthly imports }}
$$

If a ratio lasts longer than five months, it is considered to be adequate, but if it lasts less than one month it could represent a worrisome situation.

- Debt Service Ratio (DSR) ${ }^{19} /$ Exports

- Short term debt refinancing

- Current account balance behaviour

- Liquidity Gap Ratio (LGR): another liquidity sub-ratio is the so-called "1Yr Liquidity Gap Ratio". The formula is:

$$
\frac{I M R}{\text { Imports }+1 \text { Yr.debt }}
$$

The result should be under $20 \%$ as treasury bills can be issued -in fact, they are issued- for one year, in order to clear the deficit.

- Interest Service Ratio (ISR): this is a good complement to DSR. However, DSR is a solvency indicator while ISR is a liquidity ${ }^{20}$ indicator. The difference between both ratios gives us the percentage of goods and services exported, which are necessary every year in order to afford the principal debt. Therefore, an increase in ISR means a bigger necessity to export goods and services in order to afford payments due to interests. A

\footnotetext{
${ }^{17}$ Five to ten years refers to a "medium-term".

${ }^{18}$ The Bank of Spain confirms that gold reserves on December $31^{\text {st }}, 2011$ were $€ 11,017$ million. On the other hand, and on the same date, Germany, Italy, and France, for example, owned $€ 132,874-€ 95,924-€ 95,281$ million respectively.

${ }^{19}$ Refer to formula 2.

${ }^{20}$ However, it is important to mention that the liquidity of a country does not always depend on the current account balance. In Spain, as in other developed countries, Treasury bills are a very important liquidity source.
} 
change in the ratio gives us information about the development of the external debt structure. A decrease in this ratio shows that the country can afford most of the payment of its external debt. The formula is:

$$
I S R=\frac{\text { Sovereign debt interest year } N}{\text { Commercial exports and services year } N} * 100
$$

\section{COUNTRY RISK ASSESSMENT}

Now, we are going to present an example of how this paper assess the "country risk" based on all the criteria given by the rating agencies. As mentioned, these criteria are classified in four aspects in order to facilitate the academic comprehension of the methodology.

\subsection{Global Risk Index}

As mentioned in 1.3., "Country Analysis", the final result is called Global Risk Index (GRI) and rating agencies translate it into letters (AAA, AA, A, $\mathrm{BBB}$, etc.). This Global Risk Index is made up of a group of political, economic, solvency, and liquidity indexes ${ }^{21}$, each with its specific weight, which are as follows: political index (PI) 45\%, economic index (EI) 30\%, solvency index (SI) $15 \%$, and liquidity index (LI) $10 \%$. Therefore, the weight is related to the following formula:

$$
G R I=P I * 45 \%+E I * 30 \%+S I * 15 \%+L I * 10 \%
$$

In Chart 1 , we have a summary of the complete analysis of "country risk" which will be explained later.

\section{Chart 1}

\begin{tabular}{|c|c|c|c|c|c|c|}
\hline & \multicolumn{3}{|c|}{ DECEMBER 2001} & \multicolumn{3}{|c|}{ DECEMBER 2012} \\
\hline INDEXES & $\begin{array}{l}\text { WEIGHT } \\
\text { (W) }\end{array}$ & $\begin{array}{c}\text { ASSESSMENT } \\
\text { (A) }\end{array}$ & $(W)^{*}(A)$ & $\begin{array}{l}\text { WEIGHT } \\
(\mathrm{W})\end{array}$ & $\begin{array}{l}\text { ASSESSMENT } \\
\text { (A) }\end{array}$ & $(W)^{*}(A)$ \\
\hline POLITIC & $45.0 \%$ & & & $45.0 \%$ & & \\
\hline ECONOMIC & $30.0 \%$ & & & $30.0 \%$ & & \\
\hline SOLVENCY & $15.0 \%$ & & & $15.0 \%$ & & \\
\hline LIQUIDITY & $10.0 \%$ & & & $10.0 \%$ & & \\
\hline GLOBAL RISK INDEX & ….......... & & & .............. & & \\
\hline
\end{tabular}

Global Risk Index Assessment

Source: Own elaboration.

Apart from the column, where the indexes can be seen, two main columns

${ }^{21}$ Each one of these agencies use different criteria and scores but all of them coincide in these four concepts. 
with the dates of the analysis have been included. Each one is divided into three more columns: weight, assessment, and $(W)^{*}(A)$. Weight is related to what was described in the previous paragraph. Economics and politics management of a country have a joined weight of $75 \%$. Therefore, an increase or decrease in one of those indexes defines the final mark of the "country risk".

Assessment is related to the "marks" obtained through the analysis of the corresponding indexes.

In the last column, $(W)^{*}(A)$, is the result of multiplying weight times assessment. Global Risk Index (GRI) is the addition of the values obtained in this multiplication, which is the rating of a country.

The sources of the economic, solvency, and liquidity data are from the Spanish Bank. However, for the political qualification, we tried to assume a political analyst role. Finally, the assignment of the different weights and scores of the sub-ratios ${ }^{22}$ was based on the criteria applied by both agencies, presented in Appendix 1 and 2.

In this matter, as it can be observed hereinafter in the epigraph 3.7., the final qualification obtained, based on the valuations and weights assigned by the authors, is in the line with the GRI given by the rating agencies to Spain on December $31^{\text {st }}, 2012$.

\subsection{Long-Term Country Risk Rating from the Main Agencies}

The following Chart 2 shows the "Country Risk" rating used by main longterm agencies. They use letters which are translated into marks coming from the Global Risk Index (GRI).

\section{Chart 2}

Country Risk Rating from the Main Agencies

\begin{tabular}{|c|c|c|}
\hline STANDARD \& POOR'S & MOODY'S & MARK $^{23}$ \\
\hline AAA & Aaa & 9.5 to 10 \\
\hline AA & $\mathrm{Aa} 1, \mathrm{Aa} 2, \mathrm{Aa} 3$ & 8.5 to 9.4 \\
\hline $\mathrm{A}$ & $\mathrm{A} 1, \mathrm{~A} 2, \mathrm{~A} 3$ & 8.0 to 8.4 \\
\hline BBB & Baa & 7.5 to 7.9 \\
\hline BB & $\mathrm{Ba} 1, \mathrm{Ba} 2, \mathrm{Ba} 3$ & 6.5 to 7.4 \\
\hline $\mathrm{B}$ & $\mathrm{B} 1, \mathrm{~B} 2, \mathrm{~B} 3$ & 6.1 to 6.4 \\
\hline $\mathrm{CCC}$ & Caa1, Caa2, Caa3 & 5.6 to 6.0 \\
\hline $\mathrm{CC}$ & $\mathrm{Ca}$ & 5.0 to 5.5 \\
\hline C & $\mathrm{C}$ & 5 and $>5$ \\
\hline
\end{tabular}

Source: Own elaboration.

${ }^{22}$ Some sub-ratios are based on "Economic Analysis of Countries". Pampillón Olmedo, R. (1999).

${ }^{23}$ The "mark" in the third column is an estimation based on the letters of the first two columns. 
For the explanation of the letters' meanings, refer to Appendix 3.

\subsection{Political Risk Analysis}

As was mentioned before, the first thing observed by an investor is the political scenario of the country where he would invest. Therefore, the political risk assessment (PI) is related to 16 ratios. Between them, we can point out political regime, governmental strength level, bureaucracy level, corruption range, foreign affair policies, labour policies, autonomous and independent movements, pressure groups, etc. A weight factor, depending on the importance level, is applied to each ratio, always from the investor's point of view. That means that a weight of 3 means the ratio is very important, a weight of 2 has a medium importance, and a weight of 1 is relatively important. Generally though, none of these two main rating agencies apply a weighting of 1 to political ratios. As a result, it is obvious that these ratios have an important weight on the rating of the country, which is normally between 40 and $45 \%$.

It is also important to mention that each of these 16 ratios have "sub-ratios" which are meticulously and constantly analyzed by teams formed by experts in each area. If it is confirmed that the "political regime" is only democratic, nothing is mentioned. The issues studied in these sub-ratios are, for example, maturity level of the democracy of a country, if it has a positive impact in the coexistence level of its society and, if it has a positive impact in the economic scenario. For that reason, the experts study questions such as: Is it a direct, indirect, representative or participative democracy? Does the power belong to the totality or the majority of the population? When the decisions are made, do they belong to the collective will of the population? Is this done through a mechanism of direct or indirect participation which gives legitimacy to its representatives?

Furthermore, a detailed study of the people who work in the government also forms part of the analysis: their curriculum vitae, professional experience, and policies. In addition, the results of the government period are added, among other aspects. The assessment of these factors takes into consideration governmental control, potential factors of internal disorders, and the exterior influence on political stability of the regime.

The assigned weightings $(3,2$, or 1$)$ for each ratio must be multiplied by the "marks" that the specialist team gives each ratio. This mark can oscillate from0 (very low) to 10 (very high) ${ }^{24}$ : (VL) Very Low, 0; (L) Low, 2; (M) Medium, 5; (H) High, 8; and, (VH) Very High, 10.

${ }^{24}$ As mentioned in 1.1., although these agencies have their own criterion and methodology for weighting and assessment, structures and ratios, in general, are similar. Regarding the "marks", Standard \& Poor's for example, use a scale from 1 to 6 instead of from 0 to 10 . 
The addition of the result of the multiplications divided by the sum of the weightings (in this case 45) is the "mark" that the country obtains for the political risk analysis. For further information, see Chart 3. This chart and the following 4,5 , and 6 , show a case study of the methodology used to analyze and rate Spain by rating agencies; the first one on December $31^{\text {st }}$, 2001, and the second, on December $31^{\text {st }}, 2012$. However, technical rigor of the case is based in two real facts: the worsening of Risk Premium and the Country Risk assessments from rating agencies within the last analyzed years.

\section{Chart 3}

Political Risk Assessment in Spain - December 2001 and December 2012

\begin{tabular}{|c|c|c|c|c|c|c|}
\hline & \multicolumn{3}{|c|}{ DECEMBER 2001} & \multicolumn{3}{|c|}{ DECEMBER 2012} \\
\hline & $\begin{array}{l}\text { WEIGHT } \\
\text { (W) }\end{array}$ & $\begin{array}{c}\text { ASSESSMENT } \\
\text { (A) }\end{array}$ & $(W)^{*}(A)$ & $\begin{array}{l}\text { WEIGHT } \\
\text { (W) }\end{array}$ & $\begin{array}{c}\text { ASSESSMENT } \\
\text { (A) }\end{array}$ & $(W)^{*}(A)$ \\
\hline 1. POLITICAL REGIME & 3.0 & 10.0 & 30.0 & 3.0 & 10.0 & 30.0 \\
\hline 2. PRESSURE GROUPS & 3.0 & 9.5 & 28.5 & 3.0 & 6.5 & 19.5 \\
\hline 3. GOVERNMENT STRENGTH & 3.0 & 10.0 & 30.0 & 3.0 & 7.5 & 22.5 \\
\hline 4. BUREAUCRACY & 3.0 & 9.5 & 28.5 & 3.0 & 8.0 & 24.0 \\
\hline 5. FOREIGN AFFAIR POLICIES & 3.0 & $9 . .0$ & 27.0 & 3.0 & 8.5 & 25.5 \\
\hline 6. CORRUPTION & 3.0 & 9.5 & 28.5 & 3.0 & 5.5 & 16.5 \\
\hline 7. INDEPENDENT MOVEMENTS & 3.0 & 9.0 & 27.0 & 3.0 & 5.5 & 16.5 \\
\hline 8. RELIGIOUS AND RACIAL STRUCTURE & 2.0 & 9.0 & 18.0 & 2.0 & 8.5 & 17.0 \\
\hline 9. SOCIAL STRUCTURE & 3.0 & 9.0 & 27.0 & 3.0 & 8.0 & 24.0 \\
\hline 10. INT'L ORGANIZATION MEMBERSHIP & 2.0 & 10.0 & 20.0 & 2.0 & 9.0 & 18.0 \\
\hline 11. ECONOMIC SYSTEM ${ }^{25}$ & 3.0 & 10.0 & 30.0 & 3.0 & 7.0 & 21.0 \\
\hline 12. POLITICAL AND LABOUR RELATIONS & 3.0 & 9.5 & 28.5 & 3.0 & 7.5 & 22.5 \\
\hline 13. DEMOGRAPHIC STRUCTURE & 3.0 & 10.0 & 30.0 & 3.0 & 10.0 & 30.0 \\
\hline 14. AREA AND OROGRAPHY & 3.0 & 10.0 & 30.0 & 3.0 & 10.0 & 30.0 \\
\hline 15. INTERNATIONAL CONFLICT PROBABILITY & 2.0 & 9.0 & 18.0 & 2.0 & 9.0 & 18.0 \\
\hline 16. INTERVENTION FROM THIRD COUNTRIES & 3.0 & 9.0 & 27.0 & 3.0 & 8.0 & 24.0 \\
\hline TOTAL & 45.0 & & 428.0 & 45.0 & & 356.0 \\
\hline POLITICAL INDICATOR & 9.511 & & & 7.911 & & \\
\hline
\end{tabular}

Source: Own elaboration.

As seen, the mark of the political indicator in December 2001 was 9.511, but in December 2012 this index decreased to 7.911. This was due to some political sub-ratios (shaded above) such as pressure groups, government strength, and above all, corruption scandals, and also independent movements which have appeared fiercely in the last months among political parties. As seen in Chart 3,

${ }^{25}$ This sub-ratio is related to the economic model implanted and applied by the government during the analyzed period. 
specifically sub-ratios $2,3,6,7$, and 11 [columns (W)*(A)], have decreased notoriously between December 2001 and December 2012, which caused a bad influence on the indicator.

Above all, if considered that the political indicator has a weight of $45 \%$ in the global equation of the assessment, this decrease has a higher importance in the final mark of the "country risk".

It is important to bring forward that an indicator with a mark of 10 is a politically stable country. This concept is valid for all indicators. In other words, for instance, in the economic scene, an indicator close to 10 would represent an economically strong country.

\subsection{Economic Risk Analysis}

The method of the economic risk analysis is the same. Obviously, the subratios have been changed by other economic factors mentioned in 2.2.2. For further information, see Chart 4 . The addition of the weighting is usually around 30.

Following the same structure of the political ratios, the economic indicators are divided into sub-ratios. Therefore, for the first ratio, "economic policies", it is important to remember what was mentioned in epigraph 2.2.2.

The main objective of the analysis is to assess the capacity and credibility a government team has to manage the economy, and to carry out structural changes in an appropriate way.

As seen in the chart above, the economic indicator had a mark of 9.533 on December 2001, and 7.450 on December 2012. The weakness of three sub-ratios (shaded above) such as employment, debt level, and financial system, impacted negatively on the economic scene. Besides, it is very important to mention the fiscal deficit. At the end of 2011, the outgoing government said it was 6\%. However, two months later, the new government corrected this percentage increasing it to $9 \%$. This situation shocked the international markets, and the international rating agencies immediately penalized Spain for many of the following months.

\section{Chart 4}

Economic Risk Assessment in Spain - December 2001 and December 2012

\begin{tabular}{|l|c|c|c|c|c|c|}
\cline { 2 - 8 } \multicolumn{1}{c|}{} & \multicolumn{3}{c|}{ DECEMBER 2001 } & \multicolumn{3}{c|}{ DECEMBER 2012 } \\
\cline { 2 - 8 } \multicolumn{1}{c|}{} & $\begin{array}{c}\text { WEIGHT } \\
(\mathbf{W})\end{array}$ & $\begin{array}{c}\text { ASSESSMENT } \\
(\mathbf{A})\end{array}$ & $\mathbf{( W )})^{*}(\mathbf{A})$ & $\begin{array}{c}\text { WEIGHT } \\
(\mathbf{W})\end{array}$ & $\begin{array}{c}\text { ASSESSMENT } \\
(\mathbf{A})\end{array}$ & (W) $)^{*}(\mathbf{A})$ \\
\hline 1. ECONOMIC POLICIES & 3.0 & 10.0 & 30.0 & 3.0 & 8.5 & 25.5 \\
\hline 2. ECONOMIC MANAGEMENT & 3.0 & 10.0 & 30.0 & 3.0 & 8.0 & 24.0 \\
\hline 3. FISCAL POLICIES & 3.0 & 10.0 & 30.0 & 3.0 & 8.5 & 25.5 \\
\hline
\end{tabular}


Chart 4 (continue)

Economic Risk Assessment in Spain - December 2001 and December 2012

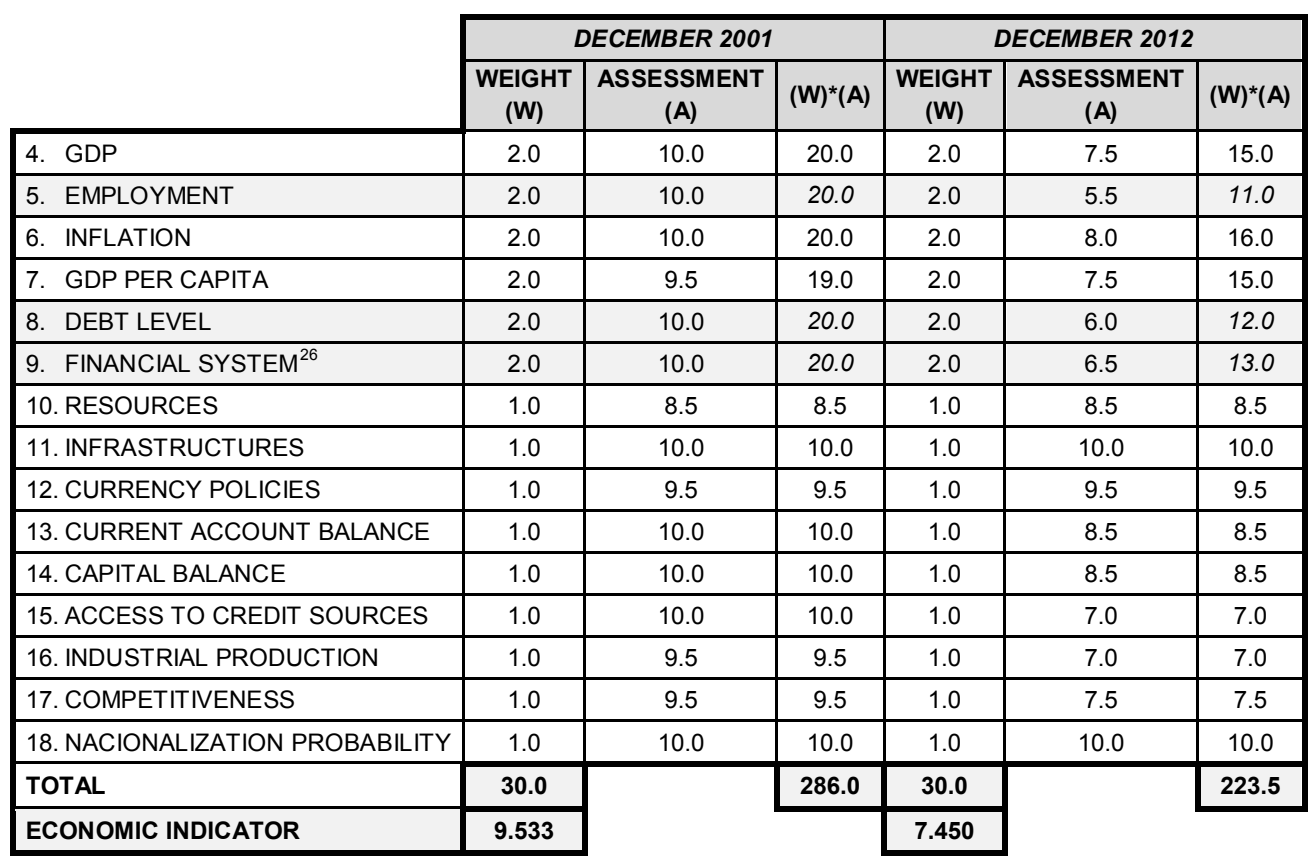

Source: Own elaboration.

\subsection{Solvency Risk Analysis}

The method used to assess the solvency of a country, that is, its capacity to afford its long-term obligations, is exactly the same of what we have seen before but, assessing the ratios related to this assessment. For further information, see Chart 5, in which can be noted -besides analysis results- that the total weight rises up to 15 .

The assessment of the long-term financial indicator shows that the mark in 2001 was 9.900, while in 2012, it decreased to 7.500. The main causes of this worsening were sub-ratios such as debt service ratio, debt structure and debt level, and public debt/GDP.

${ }^{26}$ Benmelech E. and Dlugosz J. 2009. The Alchemy of Collateralized Debt Obligation (CDO) Credit Ratings. Journal homepage: www.elsevier.com/locate/jme 


\section{Chart 5}

Solvency Risk Assessment in Spain - December 2001 and December 2012

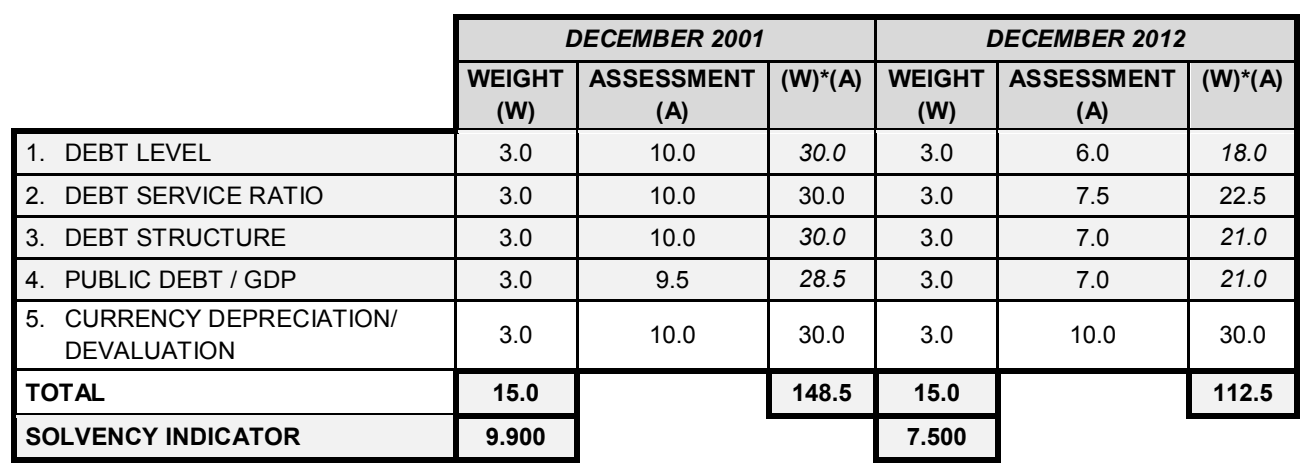

Source: Own elaboration.

\subsection{Liquidity Risk Analysis}

In accordance to Alquist R. (2005), the liquidity analysis of a country refers to its capacity to afford its short-term obligations, or the capacity to refinance it. The method used for this analysis -once the corresponding ratios have been selected- is similar to the ones used before. As an example, refer to Chart 6 which contains the final results in December 2001 and 2012. In addition, it shows that the total weight rises up to 10 .

\section{Chart 6}

Liquidity Risk Assessment in Spain - December 2001 and December 2012

\begin{tabular}{|c|c|c|c|c|c|c|}
\hline & \multicolumn{3}{|c|}{ DECEMBER 2001} & \multicolumn{3}{|c|}{ DECEMBER 2012} \\
\hline & $\begin{array}{c}\text { WEIGHT } \\
\text { (W) }\end{array}$ & $\begin{array}{l}\text { ASSESSMENT } \\
\text { (A) } \\
\end{array}$ & $(W)^{*}(A)$ & $\begin{array}{l}\text { WEIGHT } \\
\text { (W) }\end{array}$ & $\begin{array}{c}\text { ASSESSMENT } \\
\text { (A) }\end{array}$ & $(W)^{*}(A)$ \\
\hline $\begin{array}{l}\text { INT'L MONETARY RESERVES } \\
\text { / MONTHLY IMPORTS }\end{array}$ & 3.0 & 9.5 & 28.5 & 3.0 & 8.0 & 24.0 \\
\hline $\begin{array}{l}\text { DEBT SERVICES RATIO / } \\
\text { EXPORTS }\end{array}$ & 2.0 & 10.0 & 20.0 & 2.0 & 8.0 & 16.0 \\
\hline $\begin{array}{l}\text { SHORT TERM DEBT } \\
\text { REFINANCING }\end{array}$ & 1.0 & 10.0 & 10.0 & 1.0 & 8.5 & 8.5 \\
\hline IMF CREDIT & 1.0 & 10.0 & 10.0 & 1.0 & 10.0 & 10.0 \\
\hline $\begin{array}{l}\text { CURRENT ACCOUNT } \\
\text { BALANCE BEHAVIOUR }\end{array}$ & 1.0 & 10.0 & 10.0 & 1.0 & 8.0 & 8.0 \\
\hline LIQUIDITY GAP RATIO & 1.0 & 10.0 & 10.0 & 1.0 & 8.0 & 8.0 \\
\hline INTEREST SERVICE RATIO & 1.0 & 10.0 & 10.0 & 1.0 & 8.0 & 8.0 \\
\hline TOTAL & 10.0 & & 98.5 & 10.0 & & 82.5 \\
\hline LIQUIDITY INDICATOR & 9.850 & & & 8.250 & & \\
\hline
\end{tabular}

Source: Own elaboration.

The chart shows that the assessment in 2001 was 9.850, while in 2012 it 
decreased to 8.250 . It is also obvious that, as it is very close to 10 , the investors can be less worried about the liquidity of the country. By the way, it can be seen that the liquidity is the best indicator among the four. It is the only index that, in 2012 , exceeds 8.000 , a rating that could be the gateway to re-enter the "A" countries.

\subsection{Global Risk Index Estimation}

Once the four indicators have been assessed, a final assessment of the "Country Risk" is estimated. For further information, see Chart 7 -similar to Chart 1- completed with the four indexes obtained from the previous assessments.

\section{Chart 7}

Global Risk Index Assessment

\begin{tabular}{|l|c|c|c|c|c|c|}
\cline { 2 - 8 } \multicolumn{1}{c|}{} & \multicolumn{3}{c|}{ DECEMBER 2001 } & \multicolumn{3}{c|}{ DECEMBER 2012} \\
\hline INDEXES & $\begin{array}{c}\text { WEIGHTING } \\
(\mathrm{W})\end{array}$ & $\begin{array}{c}\text { ASSESSMENT } \\
(\mathrm{A})\end{array}$ & $(\mathbf{W})^{*}(\mathrm{~A})$ & $\begin{array}{c}\text { WEIGHTING } \\
(\mathrm{W})\end{array}$ & $\begin{array}{c}\text { ASSESSMENT } \\
(\mathrm{A})\end{array}$ & $(\mathbf{W})^{*}(\mathrm{~A})$ \\
\hline POLITICAL & $45.0 \%$ & 9.511 & 4.28 & $45.0 \%$ & 7.911 & 3.560 \\
\hline ECONOMIC & $30.0 \%$ & 9.533 & 2.86 & $30.0 \%$ & 7.450 & 2.235 \\
\hline SOLVENCY & $15.0 \%$ & 9.900 & 1.49 & $15.0 \%$ & 7.500 & 1.125 \\
\hline LIQUIDITY & $10.0 \%$ & 9.850 & 0.99 & $10.0 \%$ & 8.250 & 0.825 \\
\hline GLOBAL RISK INDEX & $\mathbf{9 . 6 1 0}$ & & & $\mathbf{7 . 7 4 5}$ & &
\end{tabular}

Source: Own elaboration.

The global mark of the country risk analysis in December 2001 was 9.610, while, in 2012, this decreased to 7.745. If we relate the letters used by the three main rating agencies (see Chart 2) to these marks, the downgrading of the rating is inside the studied parameters. For further information, see Chart 8 :

\section{Chart 8}

Global Risk Location on Dec $31^{\text {st }}$, 2001 and 2012 Regarding the Letters and Marks from the Main Rating Agencies

\begin{tabular}{|c|c|c|c|c|}
\hline \multirow{2}{*}{ STANDARD \& POOR'S } & \multirow{2}{*}{ MOODY'S } & \multirow{2}{*}{ ASSESSMENT } & \multicolumn{2}{|c|}{ GRI } \\
\hline & & & DEC. $.31^{\text {st }} .2001$ & DEC. $31^{\text {st }} .2012$ \\
\hline AAA & Aаa & 9.0 to 10.0 & 9.610 & \\
\hline BBB & Baa & 7.5 to 7.9 & & 7.745 \\
\hline
\end{tabular}

Source: Own elaboration.

The results of the assessment are very clear: in December 2001, Spain was part of the countries so-called " $A A A$ ". However -by the end of April 2012- The Spanish Country Risk went down to the second group, with the following as- 
sessments: Standard \& Poor's, $B B B$ (which is still good, but the lowest in the "investment level" category), and Moody's, Baa. In spite of the improvement seen in the last year, above all, in the economic aspects, the country maintains the same GRI given by both agencies; and these results coincide with our own analysis.

The great majority of opinions regarding the downgrade rating -above all, the media- are only concentrated in the final result: the country risk decrease and its impact on the risk premium. However, the methodology, criteria, and procedures are generally unknown.

\subsection{Risk Premium Behaviour, December 2001-2012}

Before the conclusion, in this section we want to show the Risk Premium behaviour and the "Country Risk" assessment for the analyzed period, from December 2001 to December 2012.

\section{Chart 9}

Risk Premium and Country Risk Assessment

\begin{tabular}{|c|c|c|c|}
\hline MONTH-YEAR & RISK PREMIUM ${ }^{27}$ & $\begin{array}{l}\text { COUNTRY RISK } \\
\text { ASSESSMENT }^{28}\end{array}$ & MARK \\
\hline Dec-2001 & $0.00 \%$ & AAA & 9.610 \\
\hline Dec-2002 & $0.00 \%$ & AAA & 9.648 \\
\hline Dec-2003 & $0.00 \%$ & AAA & 9.657 \\
\hline Dec-2004 & $0.00 \%$ & AAA & 9.662 \\
\hline Dec-2005 & $0.00 \%$ & AAA & 9.601 \\
\hline Dec-2006 & $0.06 \%$ & AAA & 9.575 \\
\hline Dec-2007 & $0.12 \%$ & AAA & 9.548 \\
\hline Dec-2008 & $0.86 \%$ & AAA & 9.224 \\
\hline Dec-2009 & $0.59 \%$ & AAA & 9.342 \\
\hline Dec-2010 & $2.49 \%$ & AA & 8.509 \\
\hline Dec-2011 & $3.26 \%$ & AA & 8.180 \\
\hline Jan-12 & $3.19 \%$ & $A$ & 8.175 \\
\hline Feb-12 & $3.17 \%$ & A & 8.177 \\
\hline Mar-12 & $3.56 \%$ & $A$ & 8.090 \\
\hline April-12 & $4.11 \%$ & BBB & 7.950 \\
\hline May-12 & $5.36 \%$ & BBB & 7.850 \\
\hline Jun-12 & $4.75 \%$ & BBB & 7.780 \\
\hline Jul-12 & $5.46 \%$ & BBB & 7.650 \\
\hline
\end{tabular}

\footnotetext{
${ }^{27} \mathrm{http} / / / \mathrm{www}$.datosmacro.com/prima-riesgo

${ }^{28}$ Chart 2, presents the letters used by Standard \& Poor's.
} 
Chart 9 (continue)

Risk Premium and Country Risk Assessment

\begin{tabular}{|c|c|c|c|}
\hline MONTH-YEAR & RISK PREMIUM & $\begin{array}{c}\text { COUNTRY RISK } \\
\text { ASSESSMENT }\end{array}$ & MARK \\
\hline Aug-12 & $5.52 \%$ & BBB & 7.510 \\
\hline Sept-12 & $4.50 \%$ & BBB & 7.580 \\
\hline Oct-12 & $4.15 \%$ & BBB & 7.760 \\
\hline Nov-12 & $3.93 \%$ & BBB & 7.758 \\
\hline Dec-12 & $3.95 \%$ & BBB & 7.745 \\
\hline
\end{tabular}

Source: Own elaboration.

Figure 1

Graphic of the Risk Premium and Country Risk Assessment

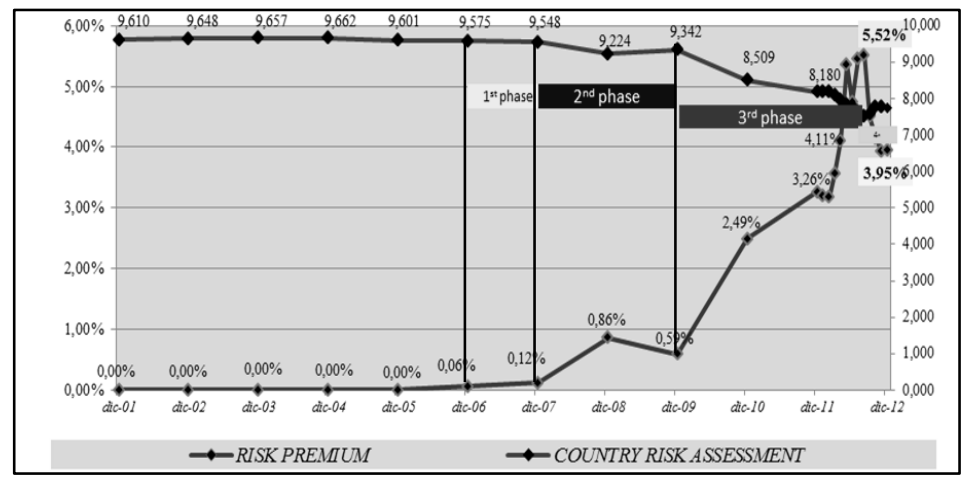

Source: Own elaboration.

We can see that the Risk Premium in Spain for December 2001 and December 2005 was $0 \%$. This means that the differential between interest rate paid with bonds issued by the Spanish Treasury for 10 years, was similar to the German bonds for the same period ${ }^{29}$. The Country Risk assessment was over 9.600, which translates into " $A A A$ ". Nevertheless, from 2006, there was a worsening period divided into four phases: (a) from December 2006 to December 2007, the worsening was gradual but minor; (b) from the end of 2007 to 2009, the global financial crisis started and the turbulences were noticeable ${ }^{30}$; (c) from the end of 2009 to August 2012, the risk premium was $0.59 \%$ (59 basis points), and rocketed down to 5.52\% (552 basis points); and, (d) from August

${ }^{29}$ In some of the indicated months, it was even under $0.00 \%$, which means that the risk premium of the German bond was higher.

${ }^{30}$ Since risk premiums were from December $31^{\text {st }}$, the corresponding turbulences in the chart cannot be seen. However, if done with monthly Risk Premiums, turbulences would be obvious. 
2012 , until the end of 2012, we can observe a gradual decrease, a trend which continues to the present moment ${ }^{31}$.

\section{CONCLUSION}

From the analysis carried out in this paper, we can conclude that the downgrade of the Spanish Global Risk Index from " $A A A$ " 9.610 to " $B B B$ " 7.745 is not the result of a speculative manoeuvre. It does not mean that a speculation does not take part of the final result. That would be a rash statement. However, it is true that the marks are based on a rigorous analysis, whose partial results feed a mathematical methodology which combines the four mentioned ratios.

In Spain, the downgrade assessment is a logical consequence of the decrease of economic and political management quality, and the lowering behaviour of solvency and liquidity indexes for the analyzed period. And, the immediate consequence of this assessment downgrade has a negative impact on three different levels: first, it raises financing costs; second, it increases the discount factor for desired investment projects, and third -and most important- economic and social deterioration continue for most of the population.

The first two aspects, financing costs and the discount factor for public sector investment projects, will be analyzed in our following research. Regarding Spain's economic and social deterioration, it seems appropriate to comment briefly about them. All methods and criteria used in the analysis, and the latest decrease in country risk assessments, are the immediate results of the events occurred since the crisis' beginning. The grave problem is that, as always, the negative impact on economic sub-ratios ends up affecting thousands of families whose quality of life worsens and falls below the poverty line. For instance, in December 2012, Caritas and other NGOs' free community pantries ${ }^{32}$ provided food in Spain to more than 1,200,000 people, something which was completely unthinkable just years ago.

On the other hand, the last government, which started ruling the country in December 2011, has been taking structural adjustment measures, including labour and financial system reforms, co-payments for health care, and cuts in sensitive sectors such as education and health care. In addition, taxes have been increased and, very slightly, some public administration costs have been reduced. All these measures taken are aimed to decrease public deficit. These short-term decisions are very painful and punish the most vulnerable people.

\footnotetext{
${ }^{31}$ At the end of May, 2014, the risk premium was about 150 basis points, which represents a significant improvement.

${ }^{32}$ Cáritas, an institution from the Spanish Bishop's Conference, is the official confederation of charity and social action from Catholic Church. In Spain, it supplies an important supporting and social promotion service for different social groups in situation of precariousness and/or social exclusion.
} 
These actions are based on the Fiscal Pact signed by 25 countries in the European Union. Nevertheless, there are some critics who point out that there should be a balance between the mentioned adjusting measures, the expenditure growth, and actions aimed at restarting economic growth.

\section{REFERENCES}

\section{Articles:}

ALQUIST, R. (2005). How important is liquidity risk for sovereign bond risk premier? Evidence from the London stock exchange. Journal of International Economics. vol. 82, nr. 2, p. 219-229. Available in http://dx.doi.org/10.1016/j.jinteco.2010.07.007

BENMELECH, E. AND DLUGOSZ, J. (2009). The alchemy of CDO credit ratings. Journal of Monetary Economics, vol. 56, nr. 5, p. 617-634. Available in http://dx.doi.org/10.1016/j.jmoneco.2009.04.007

EATON, J.; GERSOVITZ, M. AND STIGLITZ, J. E. (1986). The Pure Theory of Country Risk. European Economic Review, vol. 30, nr. 3, p. 481-514.

GARCÍA G., S. and VICÉNS O., J. (2006). Determining factors in the measurement of the sovereign risk in the emerging countries. Revista de Economía Aplicada, Vol.241, p. 559-581. Available in http://www.revista-eea.net. Ref. e-24116.

GÜLTEKIN-KARAKAS, D., HISARCIKLILAR, M., and ÖZTÜRK, H. (2011). Sovereign risk ratings: Biased toward developed countries? Emerging Markets Finance \& Trade, vol. 47, supplement 2. p. 69.

MCALEER, M.; DA VEIGA, B. and HOTI, S. (2011). Value-at-Risk for country risk ratings. Mathematics and Computers in Simulation, vol. 81, nr. 7, p. 1454-1463. Available in http://dx.doi.org/10.1016/j.matcom.2010.06.016

\section{Books:}

DEMBINSKI, P. H. (2010). ¿Finanzas que sirven o finanzas que engañan? Madrid. Ediciones Pirámide.

PAMPILLÓN O., R. (1999). Análisis económico de países: Teoría y casos de política económica. $2^{\text {nd }}$ edition. McGraw-Hill.

MORAN, THEODORE H. (2001). Inversión extranjera directa y desarrollo. México D.F. Oxford University Press, 2001

\section{Reports from the internet:}

BANCO DE ESPAÑA. Reports of December 2001 and 2012. www.bde.es

http://www.standardandpoors.com/ratings/en/us/

http://www.fitchratings.com/web/en/dynamic/fitch-home.jsp

http://www.moodys.com/

http://www.datosmacro.com/prima-riesgo 


\section{Working papers of multilateral development institutions:}

INTER-AMERICAN DEVELOPMENT BANK (IDB). (2009). Model for Country Analysis. Washington D.C., United States.

INTERNATIONAL MONETARY FUND (IMF) (2007). Theory Aspects of the Design of Fund-supported Adjustment Program. Washington D.C., United States.

WORLD BANK (2009). An Empirical Macroeconomic Model for Country Analysis. Washington D.C., Unites States.

WORLD BANK (2009). Macroeconomic Adjustment and Growth. Washington D.C., United States. 


\section{Appendix 1}

Moody'S - Methodology for Qualify Sovereign and Supranational Long Term Bonds ${ }^{33}$

\begin{tabular}{|c|c|c|c|c|}
\hline Factor & Ratios & Weight & Sub-ratios & $\begin{array}{c}\text { Assessment } \\
\text { [Very High (15) to } \\
\text { Very low (1)] }\end{array}$ \\
\hline \multirow{7}{*}{ 1. Economic } & \multirow{3}{*}{ Growth dynamics } & \multirow{3}{*}{$40 \%$} & Average real GDP growth & \\
\hline & & & Volatility in real GDP growth & \\
\hline & & & WEF Global competitiveness index & \\
\hline & Scale of the economy & $25 \%$ & Nominal GDP $(U S \$ t-1)$ & \\
\hline & National income & $25 \%$ & GDP per capita (PPP, US\$ $\$_{\mathrm{t}-1}$ ) & \\
\hline & \multirow{2}{*}{ Adjustment factor } & \multirow{2}{*}{$10 \%$} & Diversification & \\
\hline & & & Credit boom & \\
\hline \multirow{6}{*}{$\begin{array}{l}\text { 2. Institutional } \\
\text { strength }\end{array}$} & \multirow{3}{*}{$\begin{array}{l}\text { Institutional framework and } \\
\text { effectiveness }\end{array}$} & \multirow{3}{*}{$75 \%$} & World Bank Government effectiveness index & \\
\hline & & & World Bank rule of law index & \\
\hline & & & World Bank control of corruption index & \\
\hline & \multirow{2}{*}{$\begin{array}{l}\text { Policy credibility and } \\
\text { effectiveness }\end{array}$} & \multirow{2}{*}{$20 \%$} & Inflation level & \\
\hline & & & Inflation volatility & \\
\hline & Adjustment factor & $5 \%$ & Track record of Default & \\
\hline \multirow{8}{*}{ 3. Fiscal } & \multirow{2}{*}{ Debt burden } & \multirow{2}{*}{$45 \%$} & General government Debt/GDP & \\
\hline & & & General government Debt/Revenues & \\
\hline & \multirow{2}{*}{ Debt affordability } & \multirow{2}{*}{$45 \%$} & $\begin{array}{l}\text { General government Interest } \\
\text { Payments/Revenues }\end{array}$ & \\
\hline & & & General government Interest Payments/GDP & \\
\hline & \multirow{4}{*}{ Adjustment factor } & \multirow{4}{*}{$10 \%$} & Debt trend & \\
\hline & & & $\begin{array}{l}\text { General government foreign currency } \\
\text { debt/General government debt }\end{array}$ & \\
\hline & & & Other public sector debt/GDP & \\
\hline & & & $\begin{array}{l}\text { Public sector financial assets or Sovereign } \\
\text { wealth funds/GDP }\end{array}$ & \\
\hline \multirow{10}{*}{$\begin{array}{l}\text { 4. Susceptibility } \\
\text { to event risk }\end{array}$} & \multirow{2}{*}{ Political risk } & \multirow{2}{*}{$\begin{array}{l}\text { Max. } \\
\text { function }^{34}\end{array}$} & Domestic political risk & \\
\hline & & & Geopolitical risk & \\
\hline & \multirow{2}{*}{ Government liquidity risk } & \multirow{2}{*}{$\begin{array}{l}\text { Max. } \\
\text { function }\end{array}$} & Fundamental metrics & \\
\hline & & & Market funding stress & \\
\hline & \multirow{3}{*}{ Banking sector risk } & \multirow{3}{*}{$\begin{array}{l}\text { Max. } \\
\text { function }\end{array}$} & Strength of banking system & \\
\hline & & & Size of banking system & \\
\hline & & & Funding vulnerabilities & \\
\hline & \multirow{3}{*}{ External vulnerability risk } & \multirow{3}{*}{$\begin{array}{l}\text { Max. } \\
\text { function }\end{array}$} & (Current account balance + FDI)/GDP ${ }_{t}$ & \\
\hline & & & External vulnerability indicator $(\mathrm{EVI})_{\mathrm{t}+1}$ & \\
\hline & & & Net international investment position/GDP ${ }_{t}$ & \\
\hline
\end{tabular}

33 Own elaboration based on data from the following website: https://www.moodys.com/ researchdocumentcontentpage.aspx?docid $=\mathrm{PBC} \_157547$

${ }^{34}$ The aggregation of Political, Government liquidity, Banking sector, and External vulnerability risks follows a maximum function, i.e., as soon as one area of risk warrants an assessment of elevated risk, the country's overall susceptibility to event risk is scored at that specific, elevated level. 


\section{Appendix 2}

\section{Standard and Poor'S - Methodology for Qualify Sovereign and Supranational Long Term Bonds ${ }^{35}$}

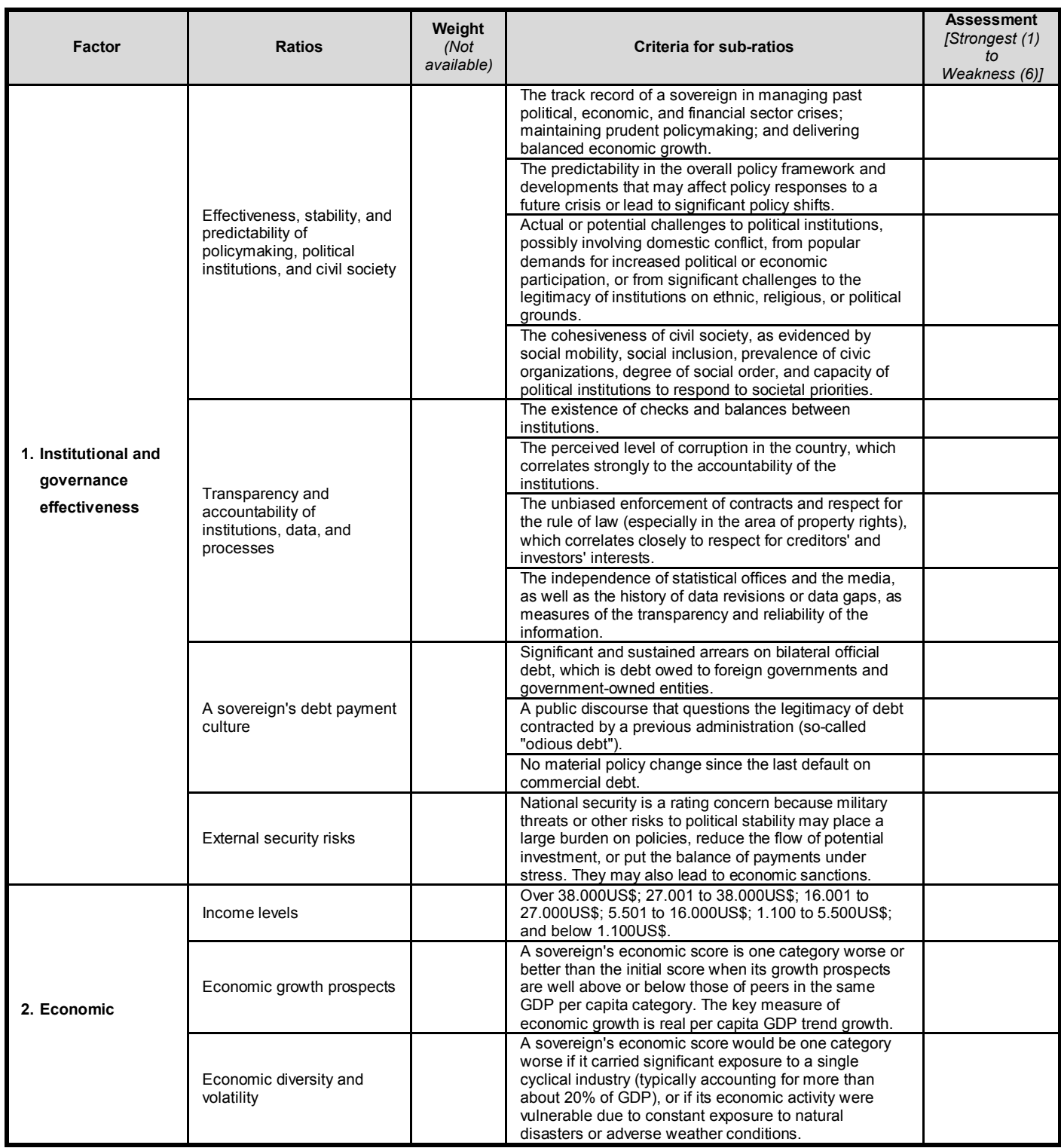

35 Own elaboration of table based on data from the following website: http://www.standardandpoors.com/prot/ratings/articles/en/eu/?articleType=HTML\&assetID=12453 56394670 


\section{Appendix 2 (continue)}

\section{Standard and Poor'S - Methodology for Qualify Sovereign and Supranational Long} Term Bonds

\begin{tabular}{|c|c|c|c|c|}
\hline Factor & Ratios & $\begin{array}{l}\text { Weight } \\
\text { (Not } \\
\text { available) }\end{array}$ & Criteria for sub-ratios & $\begin{array}{l}\text { Assessment } \\
\text { [Strongest (1) } \\
\text { to } \\
\text { Weakness (6)] }\end{array}$ \\
\hline \multirow{9}{*}{ 3. External } & \multirow{2}{*}{$\begin{array}{l}\text { Currency status in } \\
\text { international transactions }\end{array}$} & & Sovereigns with a reserve currency & \\
\hline & & & Sovereigns with an actively traded currency & \\
\hline & External liquidity & & $\begin{array}{l}\text { Gross external financing needs to the sum of current } \\
\text { account receipts plus usable official foreign exchange } \\
\text { reserves. }\end{array}$ & \\
\hline & External indebtedness & & $\begin{array}{l}\text { "Narrow net external debt" / Current account receipts } \\
\text { (CAR). } \\
\text { The term "narrow" in the description of net external debt } \\
\text { refers to a more restricted measure of assets than } \\
\text { some widely used international definitions of net } \\
\text { external debt. }\end{array}$ & \\
\hline & \multirow{2}{*}{$\begin{array}{l}\text { Adjustments for the trend } \\
\text { and funding composition of } \\
\text { the balance of payments }\end{array}$} & & $\begin{array}{l}\text { The sovereign controls an actively traded currency and } \\
\text { displays a current account surplus, on average, over } \\
\text { the last historical year, the current year, and the next } \\
\text { two forecast years. }\end{array}$ & \\
\hline & & & $\begin{array}{l}\text { The country has significant and liquid nonfinancial } \\
\text { private-sector external assets, income-earning net } \\
\text { direct investment abroad, and net portfolio equity } \\
\text { investment abroad. }\end{array}$ & \\
\hline & $\begin{array}{l}\text { Specific considerations for } \\
\text { members of monetary } \\
\text { unions }\end{array}$ & & $\begin{array}{l}\text { Each sovereign that belongs to a monetary union } \\
\text { receives an external score based on its individual } \\
\text { external position, and depending on the currency of the } \\
\text { union. This is because the external liquidity and } \\
\text { balance sheet situations of members of a monetary } \\
\text { union may vary greatly, even though they all share a } \\
\text { common currency and common capital markets. }\end{array}$ & \\
\hline & Effect of official funding & & $\begin{array}{l}\text { A sovereign's participation in an official program, such } \\
\text { as IMF programs, may affect the evolution of its } \\
\text { external performance. }\end{array}$ & \\
\hline & $\begin{array}{l}\text { Sovereigns with limited } \\
\text { external data }\end{array}$ & & $\begin{array}{l}\text { A few sovereigns do not have sufficient data on } \\
\text { external financials and flows for Standard \& Poor's to } \\
\text { apply the previously described criteria for determining } \\
\text { the external score. These sovereigns predominately } \\
\text { use the currency of another sovereign as legal tender in } \\
\text { their own jurisdictions. Several are offshore financial } \\
\text { centres }\end{array}$ & \\
\hline \multirow{4}{*}{ 4. External } & \multirow{2}{*}{$\begin{array}{l}\text { Fiscal performance and } \\
\text { flexibility }\end{array}$} & & Fiscal performance & \\
\hline & & & $\begin{array}{l}\text { Fiscal flexibility, long-term fiscal trends, and } \\
\text { vulnerabilities }\end{array}$ & \\
\hline & \multirow{2}{*}{ Debt burden } & & Access to funding and debt structure & \\
\hline & & & Contingent liabilities & \\
\hline \multirow{7}{*}{ 5. Monetary } & \multirow{3}{*}{ Exchange rate regime } & & Reserve currency & \\
\hline & & & Actively traded & \\
\hline & & & $\begin{array}{l}\text { Managed float, crawling pegs, crawl-like arrangements } \\
\text { floating with a short track record or challenged by the } \\
\text { effect of interest rate on capital flows }\end{array}$ & \\
\hline & \multirow{4}{*}{$\begin{array}{l}\text { Monetary policy's credibility } \\
\text { and effectiveness and } \\
\text { inflation trends }\end{array}$} & & $\begin{array}{l}\text { A sovereign's ability to use monetary policy and the } \\
\text { exchange rate regime. }\end{array}$ & \\
\hline & & & $\begin{array}{l}\text { Development level of financial system and capital } \\
\text { markets. }\end{array}$ & \\
\hline & & & Negative adjustments to the initial monetary score. & \\
\hline & & & Sovereigns in monetary unions. & \\
\hline
\end{tabular}




\section{Appendix 3}

\section{Acronyms Used by Standard \& Poor's and Moody'S to Rate Countries}

- $A A A$ and Aaa: High credit quality. The ratings "AAA" denote the lowest expectation of credit risk reduced. They are assigned only in cases where there is an exceptionally strong capacity to repay on time the principal and interest of a country's financial obligations.

- $A A$ and $A a 1, A a 2, A a 3$ : Very high credit quality. The "AA" ratings indicate that there is an expectation of very low credit risk. The ability for repayment of principal and interest on a timely basis is very strong. This capacity is not significantly vulnerable to foreseeable events.

- $A$ and A1, A2, A3: High credit quality. The "A" ratings denote expectations of low credit risk. The ability for repayment of principal and interest on a timely basis is strong. But this ability may be more vulnerable to changes in circumstances and economic conditions compared with higher ratings.

- $B B B$ and Baa: Good credit quality. The "BBB" ratings indicate that there is an expectation of low credit risk. The ability for repayment of principal and interest on a timely basis is adequate, but adverse changes in circumstances and economic conditions may affect this ability. It is the lowest score in the category of "investment grade".

- $B B$ and $B a 1, B a 2, B a 3$ : Speculative. The ratings "BB" indicate that there is a possibility of credit risk arising mainly as a result of an adverse change in the economic situation. However, business or financial alternatives may allow financial obligations to be fulfilled. Securities rated in this category are not investment grade.

- $B$ and $B 1, B 2, B 3$ : Highly speculative. The "B" ratings indicate a significant credit risk, but a limited margin of safety. They are meeting financial obligations, however, continued payment depends on a favourable, and stable, economic and business environment.

- $C C C, C C, C$, and Caa1, Caa2, Caa3, Ca, C: Poor position and subject to very high credit risk. The default is a real possibility. The ability to meet financial obligations is based exclusively on a business capacity and a sustained favourable economic development. A rating of "CC" indicates that default appears probable. The rating " $\mathrm{C}$ " indicates an imminent default.

- Agencies also included within each group some intermediate grades. For example, in the case of Standard \& Poor's, "AA +" or "AA-", etc. 